\title{
Алла Шевенко
}

молодиий науковий співробітник відділу психологї̈ праці

Інституту педагогічної освіти і освіти дорослих

імені Івана Зязюна НАПН України,

м. Київ, Україна, e-mail:shevenkoalla@ukr.net

https//orcid.org/0000-0002-6936-0579

\section{ВПЛИВ ПРОФЕСІЙНОГО САМОВИЗНАЧЕННЯ НА ОСОБИСТІСНЕ ЗРОСТАННЯ СТАРШОКЛАСНИКІВ}

\begin{abstract}
Анотація. У статті подано теоретичний аспект проблеми професійного самовизначення старшокласників та зазначено, що проблемою професійного самовизначення старшокласників займалися як вітчизняні, так i зарубіжні дослідники, зокрема Є. О. Клімов, Н. А. Побірченко, Б. О. Федоришин зазначали, що процес професійного самовизначення потребує активізації самопізнання особистості. Е. Ф. Зеєр, М. С. Пряжніков, Г. В. Резапкіна, С. М. Чистякова надають перевагу усвідомленому професійному самовизначенню. О. Л. Мерзлякова наголошує на доцільності використання тренінгових занять щодо ефективності здійснення професійного самовизначення старшокласниками. Але існують напрями, де недостатньо висвітлено процеси, які мають вплив на якість професійного самовизначення старшокласників.

У зв’язку з цим, пропонується модель цілеспрямованого професійного самовизначення старшокласників як чинника особистісного зростання, яка вміщує в себе когнітивно-рефлексивний, ціннісно-смисловий та поведінковомоделюючий компоненти.
\end{abstract}

Запропонована модель активізуе та оптимізує процес професійного самовизначення через опрацювання навчально-розвивального факультативу «Професійне самовизначення та особистісне зростання старшокласників», роботу 3 практикумом та проведенням тренінгових занять, а також створенням профорієнтаційного портфоліо старшокласників. Запропонована модель цілеспрямованого професійного самовизначення старшокласників базується на фундаментальних наукових знаннях, передбачає нові наукові підходи до організації цього процесу, враховує психолого-педагогічні умови розвитку особистості, забезпечує тенденцію до особистісного зростання старшокласників, сприяє якісним змінам показників та критеріїв процесу професійного самовизначення старшокласників.

Серед психологічних детермінант впливу професійного самовизначення на особистісне зростання зазначено: метод самопізнання, метод виявлення цінностей зростання особистості, метод проектування професійного «Я». Професійне самовизначення старшокласників, це складний, цілеспрямований та багатоетапний процес, який передбачає не лише вибір професії, а й тенденцію до 
зростання старшокласників в особистісному плані. Реалізація цього процесу має свої особливості та специфіку, зазначений процес здійснюється завдяки самопізнанню, саморефлексіі, комплексу особистісно-орієнтованих та інтерактивних методів роботи з учнями та сприяє якісним особистісним змінам та саморозвитку учнів.

Отже, 3 урахуванням вищезазначеного зазначено, що професійне самовизначення старшокласників, це спеціально організований процес, ефективність якого визначається особливостями організації профорієнтаційної роботи у навчальному закладі. Важливим аспектом $\epsilon$ не кількість проведених профорієнтаційних заходів, а якість виконання тих чи інших професійно спрямованих заходів. Показником ефективності виступає рівень засвоєння старшокласниками професійно орієнтованих компетенцій, а це можливо за рахунок цілеспрямованості зазначеного процесу.

Ключові слова: самовизначення, професійне самовизначення, цілеспрямоване професійне самовизначення, особистісне зростання, старшокласники.

\title{
Alla Shevenko
}

junior Researcher of the Department of Labor Psychology of the Institute of Pedagogical Education and Adult Education named after Ivan Zyazyun of the National Academy of Pedagogical Sciences of Ukraine

Kyiv, Ukraine, e-mail: shevenkoalla@ukr.net, https//orcid.org/0000-0002-6936-0579

\section{THE INFLUENCE OF PROFESSIONAL SELF-DETERMINATION ON THE PERSONAL GROWTH OF SENIOR STUDENTS}

\begin{abstract}
The article presents the theoretical aspect of the problem of professional self-determination of high school students and notes that the problem of professional self-determination of high school students was studied by both domestic and foreign researchers, in particular E. Klimov, N.Pobirchenko, B. Fedoryshyn needs to intensify self-knowledge of the individual. E.Zeyer, M. Pryazhnikov, G.Rezapkina, S. Chistyakova prefer conscious professional self-determination. O.Merzlyakova emphasizes the expediency of using training sessions on the effectiveness of professional self-determination by high school students. But there are areas where the processes that affect the quality of professional self-determination of high school students are insufficiently covered.

In this regard, we propose a procedural model of professional self-determination of high school students as a factor of personal growth, which includes cognitive-reflexive, value-semantic and behavioral-modeling components.

The proposed model activates and optimizes the process of professional selfdetermination through the development of educational and developmental electives "Professional self-determination and personal growth of high school students", work
\end{abstract}


with workshops and training sessions, as well as creating a career portfolio of high school students. The proposed model of purposeful professional self-determination of high school students is based on fundamental scientific knowledge, provides new scientific approaches to the organization of this process, takes into account psychological and pedagogical conditions of personal development, provides a tendency to personal growth of high school students, promotes qualitative changes.

Among the methods that form the basis of a purposeful process of professional self-determination are: the method of self-knowledge, the method of identifying the values of personal growth, the method of designing a professional "I". Professional selfdetermination of high school students is a complex, purposeful and multi-stage process, which involves not only the choice of profession, but also the tendency to increase high school students in personal terms. The implementation of this process has its own features and specifics, this process is carried out through self-knowledge, self-reflection, a set of personality-oriented and interactive methods of working with students and promotes quality personal change and self-development of students.

Thus, taking into account the above, we should note that the professional selfdetermination of high school students is a specially organized process, the effectiveness of which is determined by the peculiarities of the organization of career guidance work in the school. An important aspect is not the number of career guidance activities, but the quality of implementation of certain professionally oriented activities. An indicator of efficiency is the level of mastering by high school students of professionally oriented competencies, and this is possible due to the purposefulness of this process.

Keywords: self determination, professional self - determination, purposeful professional self - determination, personal growth, school students.

Постановка проблеми. Проблема вибору майбутньої професії учнями у закладах загальної середньої освіти потребує системного оновлення підходів та методів роботи. У практиці психологічної науки існує безліч трактувань поняття «самовизначення», «професійне самовизначення», «особистісне зростання». Розглядаючи сутність понять «самовизначення», «професійне самовизначення», передусім звернемося до сучасних словників, які відображають певну інтеграцію всіх існуючих підходів до визначення зазначених понять. Поняття «самовизначення» розглядається як процес і результат вибору особистістю своєї позиції, мети, засобів самоіснування в конкретних обставинах життя, як основний механізм набуття і прояву людиною свободи. Самовизначення стає важливою складовою частиною життєво важливих рішень. Сутність цього процесу полягає в активному виявленні та ствердженні індивідуальної позиції особистості. Результатом самовизначення передбачається вихід людини на мету, напрями та способи активності, здатності через цілеспрямованість самостійно реалізувати своє призначення.

Також, ми розуміємо поняття «самовизначення», як усвідомлений вибір позиції у життєвій ситуації, ставлення до чогось, активне відстоювання своєї точки зору.

За визначенням Н. А. Побірченко «самовизначення»-це процес прийняття 
життєво значимих рішень в різних сферах життєдіяльності людини. Безперечним $\epsilon$ той факт, що центральним моментом самовизначення людини $\epsilon$ здійснення життєвого вибору, який конкретизується у професії. Життєве самовизначення включає в себе соціальне самовизначення, особистісне самовизначення та професійне самовизначення. Тобто, професійне самовизначення $\epsilon$ складовою життєвого самовизначення, воно пов'язане з реалізацією творчого і виконавчого потенціалу особистості в трудовій діяльності[1].

Поняття «професійне самовизначення» розглядається як процес, що охоплює весь період професійної діяльності особистості: від виникнення професійних намірів до виходу з трудової діяльності. Цей факт свідчить про неперервність процесу професійного самовизначення, який триває упродовж життя і тим самим спонукає особистість до якісних змін, що відбуваються у всіх сферах особистості (когнітивній, ціннісно-смисловій, поведінковій).

Аналіз останніх досліджень та публікацій. Найбільш послідовно та різнобічно проблема професійного самовизначення старшокласників розглядається у роботах Е. Зеєра, Є. Клімова, М. Пряжнікова, Г. Резапкіної, В. Синявськго, Н. Побірченко, Б. Федоришина. Значення відповідального ставлення до свого професійного майбутнього висвітлювалося у роботах А. Лукіянчук, Г. Резапкіної, М. Садової, Г. Татаурової-Осики та ін. Значна увага саморозвитку та самореалізації приділялася Л. Анциферовою, Г. Баллом, Є. Сгоровою, Є. Клімовим, І. Коном, А. Лукіянчук, Н. Побірченко, Г. Резапкіною, В. Синявським, С. Чистяковою Б. Федоришиним ін. У віковій психології i психології розвитку проблема самовизначення особистості вивчається у зв'язку із специфікою раннього юнацького віку, процесами формування світогляду, соціалізації і вибору сфери професійної діяльності Р. Бернс, Л. Божович, I. Дубровіна, I. Кон, А. Мудрик, Ф. Райс, Х. Ремшмидт, П. Шавір, та ін.

Мета статті: визначити психологічні детермінанти впливу цілеспрямованого професійного самовизначення на особистісне зростання старшокласників.

Виклад основного матеріалу. Цілеспрямоване професійне самовизначення старшокласників - це складний, цілеспрямований та багатоетапний процес, який передбачає не лише вибір професії, а й тенденцію до зростання старшокласників в особистісному плані. Реалізація цього процесу має свої особливості та специфіку, зазначений процес здійснюється завдяки самопізнанню, саморефлексії, комплексу особистісно-орієнтованих та інтерактивних методів роботи з учнями та сприяє якісним особистісним змінам та саморозвитку учнів. Цілеспрямоване професійне самовизначення грунтується на принципах науковості, системності, послідовності, інтеграції та свободи вибору. Воно здійснюється за умов застосування індивідуального підходу, що грунтується на врахуванні потреби ставлення до учня як до суб'єкта діяльності, врахування відмінностей індивідуально-типологічних рис, характеру, здібностей тощо. Однією з важливих умов цілеспрямованого професійного самовизначення учнів $є$ залучення їх до активної самопізнавальної діяльності, бо самопізнання сприяє саморозвитку та самоактуалізації особистості. Самоактуалізована особистість прагне до найбільш повного виявлення, усвідомлення, розвитку та реалізації своїх особистісних 
можливостей. Необхідною умовою особистісного зростання $\epsilon$ усвідомлення цінностей росту, а саме: включення у процес активних змін старшокласників, їх готовність та здатність виходити із зони комфорту, напрацьовувати нові поведінкові моделі та стратегії, робити свідомий вибір та брати на себе відповідальність за результати власної діяльності. До умов цілеспрямованого професійного самовизначення варто також долучити набуття навиків моделювання образу професійного «Я», проектування власного професійного майбутнього.

3 метою активізації професійного самовизначення учнів нами створено модель впливу цілеспрямованого професійного самовизначення на особистісне зростання старшокласників (рис 1.).

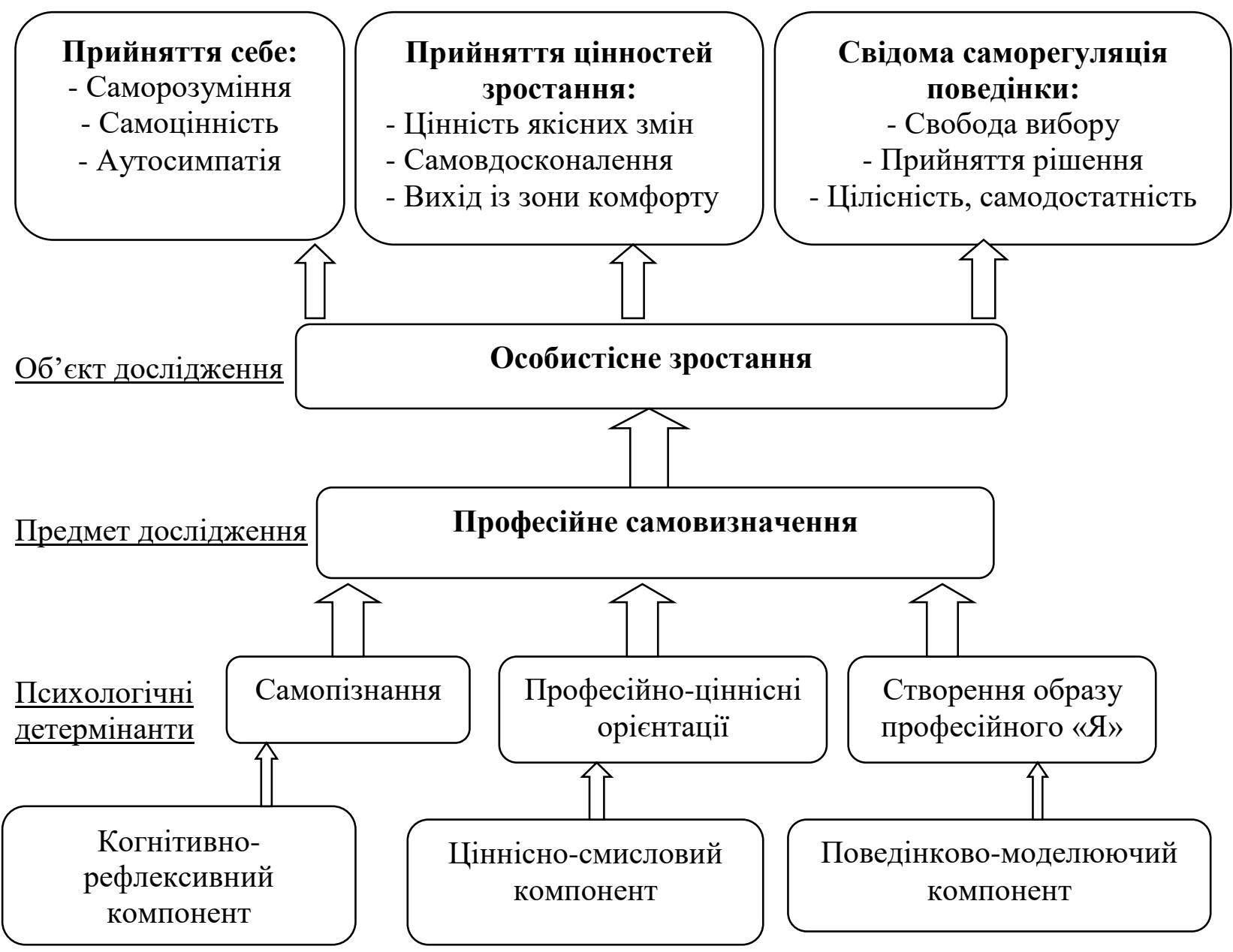

Рис. 1. Модель впливу цілеспрямованого професійного самовизначення на особистісне зростання старшокласників

Визначено, що процес професійного самовизначення старшокласників доцільно розглядати у відповідності до рівнів сформованості структурних компонентів цілеспрямованого професійного самовизначення. Високий рівень розвитку когнітивно-рефлексивного компонента передбачає залучення старшокласників до активного самопізнання, результатом якого є грунтовні 
знання власних індивідуально-типологічних особливостей, розуміння сильних сторін та способів їх вдалого використання, постійна зацікавленість тематикою вибору професії. Високий рівень розвитку ціннісно-смислового компонента засвідчує сформованість у старшокласників цінностей праці та цінностей зростання, наявність стійкого прагнення до самовдосконалення. Високий рівень поведінково-моделюючого компонента передбачає усвідомлення старшокласниками відповідальності за вибір майбутньої професії, здатність приймати обгрунтовані рішення, готовність до моделювання професійного «Я». Детермінантами виступають процес самопізнання, формування професійноціннісних орієнтацій, створення образу професійного «Я». До методів професійного самовизначення віднесено метод самопізнання старшокласниками власних індивідуально-типологічних особливостей; метод діагностики та самодіагностики (спостереження, бесіда, анкетування, тестування учнів) у процесі професійного самовизначення; метод моделювання професійного «Я» старшокласників; метод створення профорієнтаційного простору, у якому відбувається цілеспрямоване професійне самовизначення старшокласників.

Запропонована модель впливу цілеспрямованого професійного самовизначення старшокласників на особистісне зростання активізує та оптимізує цей процес під час опрацювання комплексної навчально-розвивальної програми професійного самовизначення старшокласників, роботи з практикумом зазначеної програми, проведенням тренінгових занять, а також створення профорієнтаційного портфоліо учнів.

У експериментальному дослідженні впливу професійного самовизначення старшокласників на особистісне зростання старшокласників досліджувався вплив психологічних детермінант професійного самовизначення на особистісне зростання старшокласників, приведено результати дослідження розвитку кожного $з$ компонентів професійного самовизначення старшокласників, представлено результати дослідження рівнів сформованості компонентів професійного самовизначення.

Виходячи 3 теоретичного аналізу проблеми, розроблено емпіричну модель цілеспрямованого професійного самовизначення старшокласників як чинника особистісного зростання (Табл. 1).

\section{Табличя 1}

Емпірична модель дослідження професійного самовизначення старшокласників як чинника особистісного зростання

\begin{tabular}{|c|c|c|c|}
\hline \multirow[t]{2}{*}{$\begin{array}{l}\text { Компо } \\
\text { ненти }\end{array}$} & \multirow[t]{2}{*}{$\begin{array}{l}\text { Крите } \\
\text { рії }\end{array}$} & $\begin{array}{c}\text { Дихотомічні шкали } \\
\text { (показники) }\end{array}$ & Психодіагностичні методики \\
\hline & & \multicolumn{2}{|c|}{ Професійне самовизначення } \\
\hline \multirow{3}{*}{ 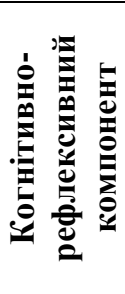 } & \multirow{3}{*}{ 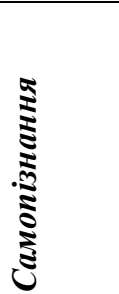 } & $\begin{array}{l}\text { Саморозуміння } \\
\text { (розуміння себе - нерозуміння себе) }\end{array}$ & \multirow{3}{*}{$\begin{array}{l}\text { Тест-опитувальник САМОАЛ } \\
\text { Тест-опитувальник суб’єктивної } \\
\text { локалізації контролю (СЛК), С. Пантелєєв, } \\
\text { В. Столін; } \\
\text { Проективна експрес-методика «Коло } \\
\text { відповідальності», А. Шевенко }\end{array}$} \\
\hline & & $\begin{array}{l}\text { Самоставлення } \\
\text { (прийняття себе - неприйняття себе) }\end{array}$ & \\
\hline & & $\begin{array}{l}\text { Ставлення до професійного майбутнього } \\
\text { (прийняття відповідальності на себе - } \\
\text { перекладання відповідальності на інших) }\end{array}$ & \\
\hline
\end{tabular}


Věda a perspektivy ${ }^{\circ}$ ISSN 2695-1584 (Print)

ISSN 2695-1592 (Online)

\begin{tabular}{|c|c|c|c|}
\hline \multirow{3}{*}{ 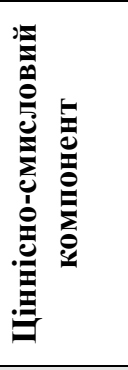 } & \multirow{3}{*}{ 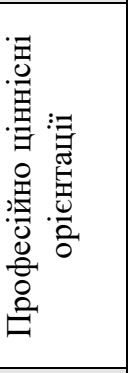 } & $\begin{array}{l}\text { Цінність праці } \\
\text { (праця, це цінність - працюють невдахи) }\end{array}$ & $\begin{array}{l}\text { Анкета для старшокласників «Мої } \\
\text { міркування щодо професійного } \\
\text { майбутнього», Н. Побірченко. }\end{array}$ \\
\hline & & $\begin{array}{l}\text { Цінності самовдосконалення } \\
\text { (цінність якісних змін - ігнорування } \\
\text { якісних змін) }\end{array}$ & Готовність до саморозвитку, В. Павлов \\
\hline & & $\begin{array}{l}\text { Досягнення } \\
\text { (цінність досягнень - знецінення } \\
\text { досягнень) }\end{array}$ & $\begin{array}{l}\text { Тест «Сенсожиттєві орієнтації» СЖО, } \\
\text { адапт. Д. Лєонтьєв }\end{array}$ \\
\hline \multirow{3}{*}{ 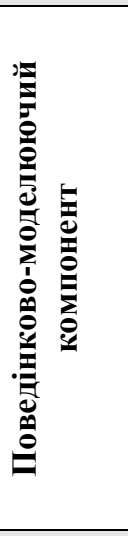 } & \multirow{3}{*}{ 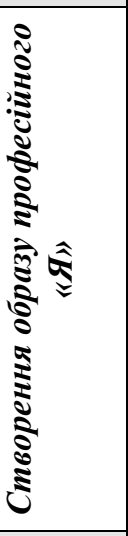 } & $\begin{array}{l}\text { Професійні уподобання } \\
\text { (власні професійні уподобання - } \\
\text { нав’язані професійні уподобання) }\end{array}$ & $\begin{array}{l}\text { Експрес опитувальник уподобань } \\
\text { старшокласників, Н. Побірченко. } \\
\text { Диференціально-діагностичний } \\
\text { опитувальник (ДДО), Є. Клімов } \\
\text { Анкета для батьків старшокласників «Що } \\
\text { Вам Відомо про професійне майбутнє } \\
\text { Вашої дитини?», А. Шевенко. }\end{array}$ \\
\hline & & $\begin{array}{l}\text { Кар’єрні орієнтації } \\
\text { (побудова кар'єри - відсутність } \\
\text { кар'єрних орієнтацій) }\end{array}$ & Методика «Якорі кар’єри», Е. Шейн. \\
\hline & & $\begin{array}{l}\text { Усвідомлений вибір } \\
\text { (свідомий вибір - випадковий вибір) }\end{array}$ & $\begin{array}{l}\text { Анкета виявлення рівнів сформованості } \\
\text { професійного самовизначення, } \\
\text { А. Шевенко. }\end{array}$ \\
\hline & & \multicolumn{2}{|l|}{ Особистісне зростання } \\
\hline \multirow{3}{*}{ 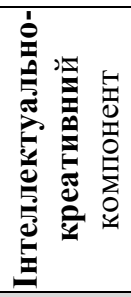 } & \multirow{3}{*}{ 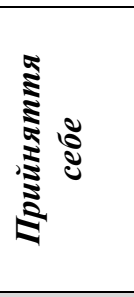 } & $\begin{array}{l}\text { Саморозуміння } \\
\text { (довіра собі/відкритість - недовіра } \\
\text { собі/закритість) }\end{array}$ & Тест-опитувальник САМОАЛ \\
\hline & & $\begin{array}{l}\text { Самоцінність } \\
\text { (самоцінність - самознецінення) }\end{array}$ & Тест-опитувальник САМОАЛ \\
\hline & & $\begin{array}{l}\text { Аутосимпатія } \\
\text { (прийняття себе - відторгнення себе) }\end{array}$ & Тест-опитувальник САМОАЛ \\
\hline \multirow{3}{*}{ 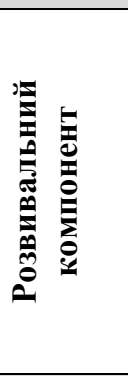 } & \multirow{3}{*}{ 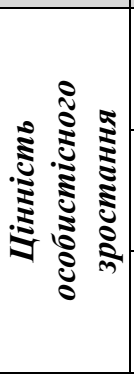 } & $\begin{array}{l}\text { Цінності зростання/якісних змін } \\
\text { (зростання, це цінність - спокій, це } \\
\text { цінність) }\end{array}$ & $\begin{array}{l}\text { Готовність до саморозвитку, В. Павлов. } \\
\text { САМОАЛ Шкала «Потреба у пізнанні» }\end{array}$ \\
\hline & & $\begin{array}{l}\text { Набуття сенсів неперервного розвитку } \\
\text { (сенс у розвитку - сенс сталого } \\
\text { перебування/відсутність сенсів) }\end{array}$ & $\begin{array}{l}\text { Тест «Сенсожиттєві орієнтації» СЖО, } \\
\text { адапт. Д. Лєонтьєв } \\
\text { САМОАЛ Шкала «Потреба у пізнанні» }\end{array}$ \\
\hline & & $\begin{array}{l}\text { Гнучкість } \\
\text { (здатність виходити із зони комфорту - } \\
\text { нездатність виходити із зони комфорту) }\end{array}$ & $\begin{array}{l}\text { Тест-опитувальник САМОАЛ } \\
\text { Шкала «Гнучкість у спілкуванні» }\end{array}$ \\
\hline \multirow{3}{*}{ 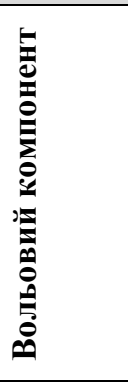 } & \multirow{3}{*}{ 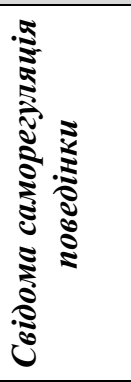 } & $\begin{array}{l}\text { Ставлення до майбутнього } \\
\text { (відповідальне ставлення - } \\
\text { безвідповідальне ставлення до } \\
\text { майбутнього) }\end{array}$ & $\begin{array}{l}\text { Визначення рівня відповідальності, } \\
\text { Г. Резапкіна. } \\
\text { САМОАЛ Шкала «Орієнтація в часі» } \\
\text { Проект. мет. «Часові кола», Н. Побірченко }\end{array}$ \\
\hline & & $\begin{array}{l}\text { Свідомий вибір } \\
\text { (прийняття відповідальності на себе - } \\
\text { звинувачення інших) }\end{array}$ & $\begin{array}{l}\text { Анкета виявлення рівнів сформованості } \\
\text { особистісного зростання, А. Шевенко. }\end{array}$ \\
\hline & & $\begin{array}{l}\text { Цілісність поведінки, самодостатність } \\
\text { (природність поведінки - штучність } \\
\text { поведінки) }\end{array}$ & $\begin{array}{l}\text { Тест-опитувальник САМОАЛ } \\
\text { Шкала «Шкала цінностей» }\end{array}$ \\
\hline
\end{tabular}

Готовність до цілеспрямованого професійного самовизначення старшокласників ми розглядали як інтегральну якість особистості, основу якої складає сукупність знань індивідуально-психологічних особливостей, цінностей та смислів до самовдосконалення, намірів щодо відповідального планування та 
моделювання власного професійного майбутнього.

Загальна кількість респондентів становила 194 учні (n=194) 9-11 класів (віком 15-17 років). Емпіричне дослідження включало в себе два етапи, перший 3 яких спрямований на виявлення кількісних та якісних показників сформованості структурних компонентів професійного самовизначення у старшокласників, другий - встановлення кореляційних зв’язків між показниками сформованості компонентів професійного самовизначення та компонентів особистісного зростання старшокласників.

За результатами констатувального експерименту, 8\% старшокласників мають низький рівень сформованості когнітивно-рефлексивного компонента, старшокласники не хочуть розбиратися в особливостях власної індивідуальнотипологічної сфери, слабко орієнтуються у своїх сильних сторонах та не замислюються над тим, як вигідно застосовувати ці ресурси у процесі життєдіяльності, не цікавляться вибором професії, не вважають його актуальним для себе. Середній рівень мають 88\% старшокласників, вони час від часу дізнаються про свої індивідуально-типологічні особливості за ініціативи практичного психолога, не завжди розуміють як правильно використати свої особливості у майбутній професії, самим вибором професії цікавляться епізодично, переважно керуючись ініціативою практичного психолога. Високий рівень сформованості когнітивно-рефлексивного компоненту професійного самовизначення присутній у 4\% старшокласників. Учні активно цікавляться власними індивідуально-типологічними особливостями, аналізуючи свої сильні сторони, розуміють як краще використати їх у майбутній професійній сфері, постійно цікавляться темою вибору професії.

Показники сформованості ціннісно-смислового компонента професійного самовизначення розподілилися наступним чином: низький рівень сформованості мають 16\% старшокласників. В учнів не сформовані цінності праці, вони не замислюються про саморозвиток та самовдосконалення, у них майже повністю відсутня відповідальність за власне професійне самовизначення. Середній рівень мають 74\% старшокласників, у них цінності праці сформовані частково, вони замислюється про самовдосконалення та саморозвиток 3 подачі шкільного психолога, соціального педагога чи класного керівника, керуючись зовнішньою мотивацією, мають часткову відповідальність за власне професійне самовизначення. Високий рівень сформованості ціннісно-смислового компоненту професійного самовизначення мають 10\% учнів, у них сформовані цінності праці, вони постійно самовдосконалюються, керуючись внутрішньою мотивацією, сформована відповідальність за власне професійне самовизначення.

Показники сформованості поведінково-моделюючого компонента професійного самовизначення старшокласників наступні: низький рівень мають 19\% старшокласників, учені майже ніколи не бере на себе відповідальність за події, що з ним відбулися; вони приймають рішення за емоційним поштовхом; вони не готові до моделювання професійного «Я», вони вважають, що подальша професія якось буде обрана сама по собі. Середній рівень мають 76\% старшокласників, вони беруть на себе відповідальність за свої вчинки за певних 
обставин; вибірково приймають рішення та не завжди здатні їх обгрунтовувати; частково готові до моделювання професійного «Я». Високий показник мають 5\% старшокласників, для них характерно брати на себе відповідальність за свої рішення та вчинки; учні переважно завжди мають обгрунтовані рішення; готові до створення образу професійного «Я».

Отже, аналізуючи отримані показники, ми можемо зробити висновки, що загальний рівень готовності до свідомого професійного самовизначення старшокласників є досить низьким (6\%), усвідомлення власної відповідальності за вибір майбутньої професії недостатньо стійке, готовність до самопізнання формальна, що керується зовнішніми факторами та пасивно-ситуативна, що не передбачає чіткої лінії сформованості образу професійного «Я».

\section{Таблиия 2}

Рівні сформованості професійного самовизначення старшокласників на констатувальному етапі

\begin{tabular}{|c|c|c|c|c|c|c|c|c|}
\hline \multirow[t]{4}{*}{ № } & \multirow{4}{*}{$\begin{array}{l}\text { Рівні сформованості } \\
\text { професійного самовизначення } \\
\text { старшокласників }\end{array}$} & \multicolumn{7}{|c|}{ Загальна вибірка, $\mathrm{n}$ - 194} \\
\hline & & \multicolumn{6}{|c|}{ Компоненти } & \multirow[b]{2}{*}{$\begin{array}{l}\text { Загальні } \\
\text { показники }\end{array}$} \\
\hline & & \multicolumn{2}{|c|}{$\begin{array}{l}\text { Когнітивно- } \\
\text { рефлексивний } \\
\text { компонент }\end{array}$} & \multicolumn{2}{|c|}{$\begin{array}{l}\text { Ціннісно- } \\
\text { смисловий } \\
\text { компонент }\end{array}$} & \multicolumn{2}{|c|}{$\begin{array}{c}\text { Поведінково- } \\
\text { моделюючий } \\
\text { компонент }\end{array}$} & \\
\hline & & $\begin{array}{l}\text { Кльк. } \\
\text { ос. }\end{array}$ & $(\%)$ & $\begin{array}{l}\text { Кльк. } \\
\text { oc. }\end{array}$ & $(\%)$ & $\begin{array}{l}\text { Кльк. } \\
\text { ос. }\end{array}$ & $(\%)$ & $(\%)$ \\
\hline 1. & Низький (пасивно-ситуативне) & 14 & $8 \%$ & 30 & $16 \%$ & 36 & $19 \%$ & $18 \%$ \\
\hline 2. & Середній (формальне) & 174 & $88 \%$ & 146 & $74 \%$ & 150 & $76 \%$ & $76 \%$ \\
\hline 3. & $\begin{array}{l}\text { Високий (свідомо- } \\
\text { цілеспрямоване) }\end{array}$ & 6 & $4 \%$ & 18 & $10 \%$ & 8 & $5 \%$ & $6 \%$ \\
\hline
\end{tabular}

Дослідження показало, що для більшості учнів (76\%) рівень професійного самовизначення відповідає формальному та має середні показники. Низький показник готовності до професійного самовизначення, що відповідає пасивноситуативному рівню професійного самовизначення мають $18 \%$ старшокласників, високий показник лише 6\%. Отже, зважаючи на такі дані буде доцільною розробка та впровадження комплексної навчально-розвивальної програми цілеспрямованого професійного самовизначення старшокласників.

Представимо рівні сформованості особистісного зростання старшокласників на констатувальному етапі дослідження. Маємо зазначити, що високий рівень сформованості мають $12 \%$ старшокласників, середній $80 \%$, низький $8 \%$. Результати за рівнями сформованості компонентів особистісного зростання старшокласників детально представлено у таблиці 3. 


\section{Таблиия 3}

Рівні сформованості особистісного зростання старшокласників на констатувальному етапі

\begin{tabular}{|c|c|c|c|c|c|c|c|c|}
\hline \multirow[t]{4}{*}{ № } & \multirow{4}{*}{$\begin{array}{l}\text { Рівні } \\
\text { сформованості } \\
\text { особистісного } \\
\text { зростання } \\
\text { старшокласників }\end{array}$} & \multicolumn{7}{|c|}{ Загальна вибірка, n - 194} \\
\hline & & \multicolumn{6}{|c|}{ Компоненти } & \multirow[b]{2}{*}{$\begin{array}{l}\text { Загальні } \\
\text { показники }\end{array}$} \\
\hline & & \multicolumn{2}{|c|}{$\begin{array}{c}\text { Iнтелектуально- } \\
\text { креативний } \\
\text { компонент }\end{array}$} & \multicolumn{2}{|c|}{$\begin{array}{c}\text { Розвивальний } \\
\text { компонент }\end{array}$} & \multicolumn{2}{|c|}{$\begin{array}{c}\text { Вольовий } \\
\text { компонент }\end{array}$} & \\
\hline & & $\begin{array}{c}\text { Кльк. } \\
\text { ос. }\end{array}$ & $(\%)$ & $\begin{array}{c}\text { Кльк. } \\
o c .\end{array}$ & $(\%)$ & $\begin{array}{c}\text { Кльк. } \\
o c .\end{array}$ & $(\%)$ & $(\%)$ \\
\hline 1. & Низький & 24 & $13 \%$ & 8 & $5 \%$ & 12 & $6 \%$ & $8 \%$ \\
\hline 2. & Середній & 146 & $74 \%$ & 180 & $91 \%$ & 142 & $73 \%$ & $80 \%$ \\
\hline 3. & Високий & 24 & $13 \%$ & 6 & $4 \%$ & 40 & $21 \%$ & $12 \%$ \\
\hline
\end{tabular}

Для встановлення психологічних закономірностей впливу особливостей професійного самовизначення на особистісне зростання старшокласників було проведено кореляційний аналіз.

Кореляційний аналіз засвідчує, що загальний показник професійного самовизначення позитивно корелює 3 показниками особистісного зростання, а саме: саморозуміння $(\mathrm{r}=0,76 ; \mathrm{p} \leq 0,01)$; аутосимпатія $(\mathrm{r}=0,57 ; \mathrm{p} \leq 0,01)$; автономність $(\mathrm{r}=0,52 ; \mathrm{p} \leq 0,01)$; гнучкість $(\mathrm{r}=0,41 ; \mathrm{p} \leq 0,01)$; творчість $(\mathrm{r}=0,40 ; \mathrm{p} \leq 0,01)$; потребою у пізнанні $(\mathrm{r}=0,35 ; \mathrm{p} \leq 0,01)$. Особливо варто відмітити стійку кореляцію 3 компонентами особистісного зростання: інтелектуально-творчий компонент ( $\mathrm{r}=0,72 ; \mathrm{p}$ $\leq 0,01)$; розвивальний $(\mathrm{r}=0,41 ; \mathrm{p} \leq 0,01)$; вольовий $(\mathrm{r}=0,47 ; \mathrm{p} \leq 0,01)$;.

Загальний показник професійного самовизначення значимо корелює 3 загальним показником особистісного зростання $(\mathrm{r}=0,63 ; \mathrm{p} \leq 0,01)$, це засвідчує значимість на рівні психологічної закономірності.

Психологічне забезпечення цілеспрямованого професійного самовизначення старшокласників як чинника особистісного зростання розглядається нами як визначення психологічних умов активізації процесу професійного самовизначення, розробки комплексної навчально-розвивальної програми цілеспрямованого професійного самовизначення старшокласників, створення профорієнтаційного простору у навчальному закладі.

На підставі аналізу результатів констатувального експерименту дослідження психологічних особливостей та умов професійного самовизначення старшокласників було розроблено комплексну навчально-розвивальну програму цілеспрямованого професійного самовизначення старшокласників. Відповідно до моделі впливу професійного самовизначення старшокласників на їх особистісне зростання та отриманих в емпіричному дослідженні результатів було розроблено комплексну навчально-розвивальну програму, спрямовану на професійне самовизначення старшокласників 3 урахуванням їх особистісного зростання. Основна мета розробки комплексної навчально-розвивальної програми полягала в здійсненні цілеспрямованого впливу на когнітивно-рефлексивний, ціннісносмисловий та поведінково-моделюючий компоненти, що спрямовані на активізацію свідомого та виваженого ставлення до власного професійного 
самовизначення.

Висновки. Отже, психологічними детермінанти впливу цілеспрямованого професійного самовизначення на особистісне зростання старшокласників виступають процес самопізнання, формування професійно-ціннісних орієнтацій та створення образу професійного «Я». Психологічними особливостями та умовами активізації професійного самовизначення старшокласників визначено внутрішні :розвиток всіх структурних компонентів професійного самовизначення старшокласників: когнітивно-рефлексивного компоненту - здійснення самопізнання та саморефлексії; ціннісно-смислового компоненту - готовність до саморозвитку, прийняття цінності праці; поведінково-моделюючого компоненту готовність до самопроектування; та зовнішні: створення профорієнтаційного простору, психолого-педагогічний супровід старшокласників у процесі професійного самовизначення, налагодження суб'єкт-суб'єктних стосунків між практичним психологом та учнями, розуміння та підтримка батьків.

Отримані дані не вичерпують усіх аспектів досліджуваної проблеми. Перспективу подальшого дослідження ми вбачаємо у впровадженні комплексної навчально-розвивальної програми цілеспрямованого професійного самовизначення та психолого-педагогічного супроводу цього процесу, що буде активізувати особистісне зацікавлення старшокласників у цілеспрямованому професійному самовизначенні. Організації низки заходів, які будуть сприяти та задовольняти ідею Нової української школи у наскрізній профорієнтації у закладах загальної середньої освіти.

\section{Лimepamypa:}

1. Побірченко, Н.А. (2009). Профорієнтація учнівської молоді [Посібник]. Київ: Наук. світ [українською мовою]. 226 с.

\section{References:}

1. Pobirchenko, N.A. (2009). Proforiyentatsiya uchashcheysya molodezhi [Vocational guidance of student youth]. Kiyev: Nauk. mir [in Ukrainian]. 